\title{
Analysis of Chemical Characteristics and Antioxidant Activity Test of Kombucha Black Tea and Butterfly Pea Flower (Clitoria ternatea L.) Based on Fermentation Time
}

\author{
Putu Rima Sintyadewi \\ Institute of Technology and Health Bali, Indonesia \\ Corresponding author email: rima.itekesbali@gmail.com \\ I Gusti Agung Yogi Rabani RS \\ Institute of Technology and Health Bali, Indonesia \\ Nadya Treesna Wulansari \\ Institute of Technology and Health Bali, Indonesia
}

\begin{abstract}
Free radicals are one of the triggering factors for degenerative diseases. Free radical activity can be minimized or prevented in the presence of antioxidant compounds. The butterfly pea flower (Clitoria ternatea L.) has long been used as a traditional medicine to cure various diseases. Previous research has shown that the Butterfly pea flower has bioactive compounds, one of which is flavonoids, which act as antioxidants. Butterfly pea flower can be used as another substitute in making black tea-based kombucha drinks. Kombucha fermentation can increase the benefits of Butterfly pea flower with the presence of organic acids, minerals, and vitamins produced during the fermentation process. This study aims to determine the effect of fermentation time on chemical characteristics including $\mathrm{pH}$, reducing sugar content, and antioxidant activity. Based on analysis of variance ANOVA showed that the length of time fermentation had a very significant effect $(P>0.01)$ on $\mathrm{pH}$, reducing sugar content and antioxidant activity of black tea and Butterfly pea flower kombucha. The longer the fermentation time, the lower the pH and sugar content in the medium. Optimum antioxidant activity occurred on the 8th day of fermentation in the variation of treatment P3 (3:3) which was $89.74 \%$. These results indicate that black tea kombucha and Butterfly pea flower are categorized as having high antioxidant activity at the interval of $68.45 \%$ to $89.74 \%$.
\end{abstract}

Keywords---black tea, butterfly pea flower, fermented drink, kombucha

\section{Introduction}

Degenerative disease is a disease due to decreased function of body organs due to deficiency of enzyme and hormone production, immunodeficiency, lipid peroxide, cell (DNA), and blood vessel damage. According to WHO, until the end of 2005, degenerative diseases had caused the death of nearly 17 million people worldwide (Yatim, 2010). Several types of degenerative diseases related to food consumption are hypertension, diabetes mellitus (DM), dyslipidemia, stroke, coronary heart disease, cardiovascular disease, obesity, and others. Free radicals are one of the triggering factors for degenerative diseases. Free radical activity can be minimized or prevented in the presence of antioxidant compounds. Antioxidant compounds are phytochemical compounds that occur naturally in plants and provide a distinctive taste, aroma, and color to these plants. Some of the properties of these phytochemical compounds function as antioxidants, improve the immune system, regulate blood pressure, lower cholesterol, and regulate blood sugar levels (Sayuti \& Yenrina, 2015).

Indonesia is a country with biodiversity that has various types of nutritious plants and has pharmacological effects for health, one of which is the Butterfly pea flower plant. Butterfly pea flower (Clitoria ternatea L.) plant grows vines and is often found in the yard of the house. C. ternatea is one of the plants that are currently popular 
among the public because it is believed to have good health benefits. According to Jacob \& Latha (2012), the Butterfly pea flower contains kaempferol which has the potential as an anti-cancer. Al-Snafi (2016), reported the pharmacological potential of Butterfly pea flower, among others, as an antioxidant, antibacterial, anti-inflammatory, analgesic, antiparasitic and anticide, antidiabetic, anti-cancer, antihistamine and immunomodulator. In the community, many processed C. ternatea L. plants are found in the form of tea. Awareness of the importance of maintaining a healthy body encourages people not only to consider aspects of taste and nutritional fulfillment in consuming food or beverages but also to consider functional aspects of food for health. Efforts that can be made to meet the community's need for healthy food or drinks are to process Butterfly pea flowers into a fermented drink (kombucha).

Kombucha is a fermented tea product using a symbiont of bacteria and yeast known as SCOBY (Symbiotic Culture of Bacteria and Yeast) (Jayabalan et al., 2014). Kombucha is generally fermented for 7-18 days at a temperature of $27 \mathrm{oC}$ to $30 \mathrm{oC}$. According to research conducted by Chakravorty et al. (2016), it is known that the polyphenol levels and antioxidant activity of kombucha increased after 7 days of fermentation. According to Nummer (2013), kombucha fermentation time is recommended no more than 10 days with a maximum $\mathrm{pH}$ of 2.5 to be consumed by humans. The tea raw materials commonly used for making kombucha are black tea, green tea, and olong tea. Black tea is the type of tea that is most easily found in the market and has a taste that people like. However, not many people know that black tea inoculated by SCOBY (kombucha) can be consumed as a health drink. According to Bhattacharya et al. (2013), kombucha tea has a higher free radical scavenging activity than black tea that has not been processed into kombucha.

Based on this, researchers are interested in making black tea kombucha with the addition of a Butterfly pea flower. Black tea is the type of tea most consumed by the public because of its taste. The effort to diversify black tea into a healthy drink is to process it into a fermented drink (kombucha) with the addition of Butterfly pea flower (Clitoria ternatea L.) which is known to have pharmacological effects on health. The purpose of this study was to determine the effect of fermentation time on the chemical characteristics and antioxidant activity of black tea and Butterfly pea flower kombucha (Jayabalan et al., 2007; Wiwekowati et al., 2017). The chemical characteristics observed included $\mathrm{pH}$ and reducing sugar content of black tea and Butterfly pea flower kombucha.

\section{Methods}

\section{Making kombucha black tea and butterfly pea flower flower}

A total of 1 liter of water is heated on a water bath for 15 minutes until the calculated temperature reaches $90 \mathrm{oC}$, then $10 \%(\mathrm{v} / \mathrm{v})$ granulated sugar is added until it dissolves then the Butterfly pea flower Simplicia is mixed based on the concentration ratio (3:1), (3:2 ) and (3:3) then filtered and put in a jar. The infusion of black tea and butterfly pea flower Simplicia is cooled to 30oC, then SCOBY is added (Chu \& Chen, 2006; Kallel et al., 2012). The fermented tea solution was filtered to clean from residue for further testing.

\section{Reducing sugar level test}

A total of $1 \mathrm{ml}$ of the sample filtrate was pipetted and then diluted in a $50 \mathrm{ml}$ volumetric flask and $1 \mathrm{ml}$ was taken for analysis. Added $1 \mathrm{ml}$ of Nelson's solution then heated to boiling for 30 minutes and cooled. Added $1 \mathrm{ml}$ of arsenomolobdate solution and shaken. Then $7 \mathrm{ml}$ of distilled water was added and the absorption was measured at a wavelength of $761 \mathrm{~nm}$ so that the reducing sugar content could be calculated (Wistiana \& Elok, 2015).

pH test

Kombucha $\mathrm{pH}$ testing was measured using a pH meter by taking a sample of $10 \mathrm{ml}$ with a dropper pipette and then measuring the $\mathrm{pH}$ using a $\mathrm{pH}$ meter.

\section{Antioxidant activity test}

The antioxidant activity test was carried out using the DPPH ( $\alpha$-diphenyl- $\beta$-picrylhydrazyl) method. 


\section{Data analysis}

This research is experimental, the data collected is quantitative. The design used in this study was a completely randomized design (CRD) with two factorials, namely factor 1 combination of black tea and Butterfly pea flower (P) which consisted of Control, P1 (3:1), P2 (3:2), and P3 ( 3:3) and factor 2 variation of fermentation time (T) namely T1 (0 days), T2 (4 days), and T3 (8 days). The data obtained were analyzed statistically with "Analysis of Variance" (Anova) and if the results obtained were significantly different at p 0.05 then the analysis was continued with Duncan's multiple distance test to see differences between treatments (Dutta \& Paul, 2019; Dufresne \& Farnworth, 2000).

\section{Results}

\section{Degree of acidity $(\mathrm{pH})$}

The degree of acidity $(\mathrm{pH})$ is a unit of measure that describes the degree of acidity or alkalinity of a solution (Pratiwi \& Aryawati 2012). $\mathrm{pH}$ control is important to be able to maintain the optimum $\mathrm{pH}$ during the fermentation process. The results of the analysis of variance ANOVA showed that the length of time of fermentation had a very significant effect $(\mathrm{P}>0.01)$ on the $\mathrm{pH}$ of black tea kombucha and Butterfly pea flower. The interaction between the combination treatments of black tea and Butterfly pea flower was significantly different with the length of fermentation time $(\mathrm{P}>0.5)$ (Table 1). The data in Table 1. shows that the $\mathrm{pH}$ of kombucha black tea and Butterfly pea flower in the combination of treatments P1, P2, and P3 tends to decrease during the fermentation process (Jayabalan et al., 2008; Mahalakshmi \& Devi, 2018). The lowest pH of black tea kombucha and Butterfly pea flower was obtained on the 8th day of fermentation in the P3 (3:3) treatment variation, which was 3.0. This shows that the higher the addition of Butterfly pea flower additives to black tea, the lower the $\mathrm{pH}$ of the medium. Changes in $\mathrm{pH}$ during the fermentation process are influenced by the sugar substrate which turns into alcohol and organic acids. The high organic acid causes the $\mathrm{pH}$ of the fermentation medium to decrease. This is in line with what was stated by Wistiana \& Elok (2015), that the decrease in $\mathrm{pH}$ during the fermentation process was caused by bacteria and yeast converting sucrose into organic acids. The formation of organic acids is the result of the metabolism of acid-forming bacteria, thereby lowering the $\mathrm{pH}$ of the medium. The decrease in $\mathrm{pH}$ in fermentation will support the life of Acetobacter xylnum bacteria in kombucha starter to carry out the metabolic activity of dissolved and dissociated acetic acid to release free protons thereby lowering the $\mathrm{pH}$ of kombucha.

Table 1

pH kombucha black tea and butterfly pea flower during fermentation

\begin{tabular}{lllll}
\hline Day of- & \multicolumn{4}{c}{ Degree of Acidity $(\mathrm{pH})$} \\
\cline { 2 - 5 } /Treatment & $\mathrm{K}$ & $\mathrm{P} 1$ & $\mathrm{P} 2$ & $\mathrm{P} 3$ \\
\hline 0 & $5.7 \pm 0.061^{*}$ & $5.1 \pm 0.06 \mathrm{k}$ & $4.9 \pm 0.01 \mathrm{j}$ & $4.7 \pm 0.11 \mathrm{i}$ \\
4 & $4.0 \pm 0.06 \mathrm{~h}$ & $3.8 \pm 0.12 \mathrm{~g}$ & $3.4 \pm 0.06 \mathrm{e}$ & $3.2 \pm 0.06 \mathrm{~cd}$ \\
8 & $3.4 \pm 0.06 \mathrm{f}$ & $3.1 \pm 0.06 \mathrm{abc}$ & $3.0 \pm 0.06 \mathrm{a}^{* *}$ & $3.0 \pm 0.06 \mathrm{ab} \mathrm{b}^{* *}$ \\
\hline - Data is displayed as the mean of 3 replicates \pm standard deviation \\
- Different lowercase superscripts showed significant differences $(P<0.05)$ \\
- **) Highest total $\mathrm{pH}$ & & \\
- *) Lowest total $\mathrm{pH}$ & & & \\
\end{tabular}

\section{Reducing sugar level}

Microbes need sugar as a carbon source. Sugar in the media will be used by microbes as a source of nutrients which are then converted into alcohol, CO2, and carbonic acid (Pratiwi \& Aryawati, 2012). The data in Table 2 shows that there was a decrease in sugar content from day 0 to day 8 fermentation in all treatments. The lowest reduction in reducing sugar occurred in treatment P3 (3:3) with a total reducing sugar of $47 \mathrm{mg} / \mathrm{ml}$. This shows that the longer the fermentation time, the more sugar used by microorganisms in the medium for their growth. According to Pratiwi \& Aryawati (2012), a decrease in sugar content indicates that every microbe requires sugar as a carbon source which is converted into alcohol and $\mathrm{CO} 2$. The resulting $\mathrm{CO} 2$ will react with water vapor and form carbonic acid. In the sugar 
fermentation process, yeast plays an active role in the decomposition of sugar into $\mathrm{CO} 2$ and organic acids, and other components.

Table 2

pH kombucha black tea and butterfly pea flower during fermentation

\begin{tabular}{llccc}
\hline Day of- & \multicolumn{4}{c}{ Reducing Sugar Level $(\mathrm{mg} / \mathrm{ml})$} \\
\cline { 2 - 5 } /Treatment & $\mathrm{K}$ & $\mathrm{P} 1$ & $\mathrm{P} 2$ & $\mathrm{P} 3$ \\
\hline 0 & $120 \pm 0.06 \mathrm{i}$ & $122 \pm 0.06 \mathrm{kl}$ & $121 \pm 0.06 \mathrm{ij}$ & $122 \pm 0.06 \mathrm{jk}$ \\
4 & $106 \pm 0.06 \mathrm{e}$ & $110 \pm 0.06 \mathrm{gh}$ & $107 \pm 0.06 \mathrm{ef}$ & $109 \pm 0.06 \mathrm{~g}$ \\
8 & $47 \pm 0.06 \mathrm{a}$ & $52 \pm 0.06 \mathrm{~d}$ & $49 \pm 0.06 \mathrm{~b}$ & $50 \pm 0.06 \mathrm{c}$ \\
\hline
\end{tabular}

- Data is displayed as the mean of 3 replicates \pm standard deviation

- Different lowercase superscripts showed significant differences $(P<0.05)$

Sugar is an important component in the process of making kombucha. Granulated sugar is the type of sugar that is most often used in making kombucha as a carbon source. During the kombucha fermentation process, the symbiosis of bacteria and yeast will convert glucose into various types of acids, vitamins, and alcohol that are beneficial for the body (Loncar et al., 2007). Wistiana \& Elok (2015), the sucrose used in kombucha does not function as a sweetener but as an energy source for bacteria to survive through fermentation and respiration processes. The decrease in reducing sugar levels was caused by the hydrolysis of sucrose into glucose by the enzyme intervase. Hydrolysis occurs because the $\mathrm{pH}$ of the medium is very low, so sucrose is easily hydrolyzed by the enzyme intervase.

\section{Antioxidant activity}

The antioxidant activity of black tea kombucha and Butterfly pea flower was tested using the DPPH method. The results of the analysis of variance ANOVA showed that the length of time of fermentation had a very significant effect $(\mathrm{P}>0.01)$ on the antioxidant activity of black tea kombucha and Butterfly pea flower (Panchariya et al., 2002; Mehmood et al., 2019). The interaction between the combination treatments of black tea and Butterfly pea flower was significantly different with the length of fermentation time ( $P>0.5)$ (Table 3$)$.

The data in Table 3 shows that the antioxidant activity of black tea kombucha and Butterfly pea flower increased with increasing fermentation time. Optimum antioxidant activity occurred in treatment P3 (3:3) on the 8th day of fermentation, which was $89.74 \%$. The research on black tea kombucha and Butterfly pea flower that was conducted previously by Sintyadewi et al. (2020), showed that an increase in flavonoid levels also occurred on day 8 of P3 (3:3) treatment, which was $68.4 \mathrm{mg} \mathrm{QE} / \mathrm{g}$ extract. This shows that the increase in flavonoid levels is in line with the increase in antioxidant activity in black tea kombucha and Butterfly pea flower. In addition, the higher the concentration of addition of Butterfly pea flower in kombucha tea, the higher the flavonoid content and antioxidant activity in the kombucha preparation.

Table 3

Kombucha black tea and butterfly pea flower antioxidant activity during fermentation

\begin{tabular}{lllll}
\hline \multirow{2}{*}{$\begin{array}{l}\text { Day of- } \\
\text { Treatment }\end{array}$} & \multicolumn{4}{c}{ Antioxidant Activity $(\mathrm{mg} \mathrm{QE} / \mathrm{g})$} \\
\cline { 2 - 5 } & $\mathrm{K}$ & $\mathrm{P} 1$ & $\mathrm{P} 2$ & $\mathrm{P} 3$ \\
\hline 0 & $61.33 \pm 0.06 \mathrm{a}$ & $68.45 \pm 0.06 \mathrm{~b}$ & $72.06 \pm 0.06 \mathrm{~cd}$ & $76.34 \pm 0.06 \mathrm{c}$ \\
4 & $67.89 \pm 0.06 \mathrm{~d}$ & $73.98 \pm 0.06 \mathrm{e}$ & $77.52 \pm 0.06 \mathrm{f}$ & $80.82 \pm 0.06 \mathrm{~g}$ \\
8 & $74.45 \pm 0.06 \mathrm{~h}$ & $79.49 \pm 0.06 \mathrm{i}$ & $83.6 \pm 0.06 \mathrm{j}$ & $89.74 \pm 0.06 \mathrm{k}^{* *}$ \\
\hline
\end{tabular}

- Data is displayed as the mean of 3 replicates \pm standard deviation

- Different lowercase superscripts showed significant differences $(P<0.05)$

- **) Highest Antioxidant Activity

Hassmy et al. (2017), during the fermentation process there was an increase in the number of organic acids due to the activity of yeast and bacteria in kombucha. Suhardini \& Zubaidah (2015), also reported increased antioxidant activity as a result of biotransformations carried out by microorganisms during the fermentation process by utilizing enzymes contained in plant cells. In addition, this is also supported by the presence of phenolic compounds contained in the basic ingredients, in this case, Butterfly pea flower, which can increase over time of fermentation. 
Another study that supports these results was reported by Suhardini \& Zubaidah (2015), who analyzed the activity of kombucha tea using various leaf substrates containing phenol, the optimum antioxidant activity was 88.24 to $92.97 \%$ on the 8th day of fermentation and decreased on the 14th day. In addition, Wulandari (2014), also reported that the antioxidant activity of kombucha tea using coffee leaves as the base material, obtained optimum antioxidant activity results on the 8th day of fermentation (89.51\%) and decreased antioxidant activity on the 12th day of fermentation (53.43). \%). Ayu et al. (2013), the decrease in antioxidant activity was caused by an acidic environment which causes phenolic compounds to become more stable and difficult to release protons that can bind to DPPH.

Wulansari \& Chairul (2011), classify antioxidant activity into several categories, namely: (1) the percentage of free radical scavenging of DPPH more than $90 \%$ are classified as having very high antioxidant activity, (2) the percentage of DPPH free radical reduction of $50-90 \%$ are classified as having antioxidant activity. high, (3) the percentage of DPPH free radical scavenging $20-50 \%$ is classified as having moderate antioxidant activity, (4) the percentage of DPPH free radical scavenging is less than $20 \%$ classified as having low antioxidant activity, and (5) the percentage of DPPH free radical scavenging is less than $0 \%$ belonging to has no antioxidant activity (Wang \& Helliwell, 2001; Liang et al., 2003). Based on this category, black tea kombucha and Butterfly pea flower are categorized as having high antioxidant activity because they are in the interval of $68.45 \%$ to $89.74 \%$.

\section{Conclusion}

The length of time of fermentation affects the degree of acidity $(\mathrm{pH})$, reducing sugar content and antioxidant activity of black tea kombucha and Butterfly pea flower. The longer the fermentation time, the lower the $\mathrm{pH}$ and reducing sugar content in the media, but it will increase the antioxidant activity. The lowest $\mathrm{pH}$ of kombucha Butterfly pea flower tea was 3.0, the lowest reduction in reducing sugar was $47 \mathrm{mg} / \mathrm{ml}$ and the optimum antioxidant activity was $89.74 \%$.

\section{References}

Al-Snafi, A. E. (2016). Pharmacological importance of Clitoria ternatea-A review. IOSR Journal of Pharmacy, 6(3), 68-83.

Ayu, S., Yan, R., \& Eka, L. (2013). Penetapan Antioksidan pada Teh Hitam Kombucha Lokal di Bali dengan Waktu Fermentasi. Bali: Universitas Udayana.

Bhattacharya, S., Gachhui, R., \& Sil, P. C. (2013). Effect of Kombucha, a fermented black tea in attenuating oxidative stress mediated tissue damage in alloxan induced diabetic rats. Food and chemical toxicology, 60, 328340.

Chakravorty, S., Bhattacharya, S., Chatzinotas, A., Chakraborty, W., Bhattacharya, D., \& Gachhui, R. (2016). Kombucha tea fermentation: Microbial and biochemical dynamics. International journal of food microbiology, 220, 63-72.

Chu, S. C., \& Chen, C. (2006). Effects of origins and fermentation time on the antioxidant activities of kombucha. Food Chemistry, 98(3), 502-507. https://doi.org/10.1016/j.foodchem.2005.05.080

Dufresne, C., \& Farnworth, E. (2000). Tea, Kombucha, and health: a review. Food research international, 33(6), 409-421. https://doi.org/10.1016/S0963-9969(00)00067-3

Dutta, H., \& Paul, S. K. (2019). Kombucha drink: production, quality, and safety aspects. In Production and management of beverages (pp. 259-288). Woodhead Publishing. https://doi.org/10.1016/B978-0-12-8152607.00008-0

Hassmy, N. P. (2017). Analisis Aktivitas Antioksidan pada Teh Hijau Kombucha Berdasarkan Waktu Fermentasi yang Optimal. PHARMACON, 6(4).

Jacob, L., \& Latha, M. S. (2012). Anticancer activity of Clitoria ternatea Linn. against Dalton's lymphoma. International Journal of Pharmacognosy and Phytochemical Research, 4(4), 207-212.

Jayabalan, R., Malbaša, R. V., Lončar, E. S., Vitas, J. S., \& Sathishkumar, M. (2014). A review on kombucha teamicrobiology, composition, fermentation, beneficial effects, toxicity, and tea fungus. Comprehensive Reviews in Food Science and Food Safety, 13(4), 538-550.

Jayabalan, R., Marimuthu, S., \& Swaminathan, K. (2007). Changes in content of organic acids and tea polyphenols during kombucha tea fermentation. Food Chemistry, 102(1), 392-398. https://doi.org/10.1016/j.foodchem.2006.05.032

Jayabalan, R., Subathradevi, P., Marimuthu, S., Sathishkumar, M., \& Swaminathan, K. (2008). Changes in freeradical scavenging ability of kombucha tea during fermentation. Food Chemistry, 109(1), 227-234. https://doi.org/10.1016/j.foodchem.2007.12.037 
Kallel, L., Desseaux, V., Hamdi, M., Stocker, P., \& Ajandouz, E. H. (2012). Insights into the fermentation biochemistry of Kombucha teas and potential impacts of Kombucha drinking on starch digestion. Food Research International, 49(1), 226-232. https://doi.org/10.1016/j.foodres.2012.08.018

Liang, Y., Lu, J., Zhang, L., Wu, S., \& Wu, Y. (2003). Estimation of black tea quality by analysis of chemical composition and colour difference of tea infusions. Food chemistry, 80(2), 283-290. https://doi.org/10.1016/S0308-8146(02)00415-6

Lončar, E. S., Malbaša, R. V., \& Kolarov, L. A. (2007). Kombucha fermentation on raw extracts of different cultivars of Jerusalem artichoke. Acta periodica technologica, (38), 37-44.

Mahalakshmi, G., \& Devi, M. A. (2018). A Study on Customer Satisfaction towards in Health Drinks in Theni District. International research journal of management, IT and social sciences, 5(2), 69-74.

Mehmood, A., Ishaq, M., Zhao, L., Yaqoob, S., Safdar, B., Nadeem, M., ... \& Wang, C. (2019). Impact of ultrasound and conventional extraction techniques on bioactive compounds and biological activities of blue butterfly pea $\begin{array}{lllll}\text { flower } \quad \text { (Clitoria } & \text { L.). Ultrasonics } & \text { sonochemistry, 51, }\end{array}$ https://doi.org/10.1016/j.ultsonch.2018.10.013

Nummer, B. A. (2013). SPECIAL REPORT: Kombucha brewing under the Food and Drug Administration Model Food Code: Risk analysis and processing guidance. Journal of environmental health, 76(4), 8-11.

Panchariya, P. C., Popovic, D., \& Sharma, A. L. (2002). Thin-layer modelling of black tea drying process. Journal of food engineering, 52(4), 349-357. https://doi.org/10.1016/S0260-8774(01)00126-1

Pratiwi, A., \& Aryawati, R. (2012). Pengaruh waktu fermentasi terhadap sifat fisik dan kimia pada pembuatan minuman kombucha dari rumput laut Sargasssum sp. Maspari Journal: Marine Science Research, 4(1), $131-136$.

Sayuti, K., \& Yenrina, R. (2015). Antioksidan alami dan sintetik. Padang. Universitas Adalas, 40.

Sintyadewi, R., Yogi, R.RS., \& Nadya, T.W. (2019). The Effect of Fermentation Time on Total Flavonoid and Organoleptic Test of Black Tea Kombucha and Butterfly pea flower (Clitoria ternatea L.). Internal Grant Report. Institute of Technology and Health Bali.

Suhardini, P. N., \& Zubaidah, E. (2015). Studi Aktivitas Antioksidan Kombucha Dari Berbagai Jenis Daun Selama Fermentasi [IN PRESS JANUARI 2016]. Jurnal Pangan dan Agroindustri, 4(1).

Wang, H., \& Helliwell, K. (2001). Determination of flavonols in green and black tea leaves and green tea infusions by high-performance liquid chromatography. Food Research International, 34(2-3), 223-227. https://doi.org/10.1016/S0963-9969(00)00156-3

Wistiana, D. \& Elok Z. (2015). Chemical and Microbiological Characteristics of Kombucha From Various Leaves High in Phenol During Fermentation. Journal of Food and Agroindustry. Vol3 No.4

Wiwekowati, W., Astawa, P., Jawi, I. M., \& Sabir, A. (2017). Antioxidant activity of Apis mellifera sp. Propolis extract from Java (Indonesia). International Research Journal of Engineering, IT and Scientific Research, 3(5), $19-24$.

Wulandari, A. (2014). Aktivitas antioksidan kombucha daun kopi (coffea arabica) dengan variasi lama waktu fermentasi dan konsentrasi ekstrak (Doctoral dissertation, Universitas Muhammadiyah Surakarta).

Wulansari, D., \& Chairul, C. (2011). Antioxidant screening activity of several Indonesian medicinal plants using 2 , 2-Difenil 1-1 Picrylhidrazyl (DPPH). Majalah Obat Tradisional, 16(1), 22-25.

Yatim, F. (2010). Kendalikan obesitas dan diabetes: mengatur pola hidup dan pola makan. Jakarta: Sarana Pustaka. 